\title{
USAGE OF AN ENTOMOPATHOGENIC NEMATODE AGAINST SUBTERRANEAN TERMITE IN LAB AND FIELD
}

\author{
EL-BASSIOUNY, A. R., M. K. ABBAS, \\ NAGLAA F. REYAD and RANDA M. ABD EL-RAHMAN
}

Plant Protection Research Institute, ARC, Dokki, Giza

(Manuscript received 20 April 2015)

\begin{abstract}
$\mathrm{U}$ sing of the pathogenic nematodes Steinernema scapterisci, against subterranean termite Psammotermes hybostoma (Desn.), under laboratory conditions, showed that, it was more effective at concentration 4000,2000 and $1000 \mathrm{IJs} / \mathrm{ml}=10$ IJs/ insect. In addition the highest rate of mortalities were in the $4^{\text {th }}$ day in all treatments, then decreased to reach to minimum in $7^{\text {th }}$ day. The nymphs were more susceptible and died faster than adult workers and soldiers. The statistical analysis showed significant differences among treatments. The present work has been conducted to test of termite traps contained entomopathogenic nematode Steinernema scapterisci, against subterranean termite Psammotermes hybostoma (Desn.), under field conditions. Data showed that, using the tested pathogenic nematodes treated once/year were effective throughout the $3^{\text {rd }}$ months after treatment (Jan., Feb., and March), when treatment with the entomopathogenic nematode was replicated 4 times/year, the efficiency was not significantly higher.

Key Words: S. scapterisci; PVC trap; corrugated card-board; Jelly agar; $P$. hybostoma; Reduction\%; Nematode development; termite symptoms.
\end{abstract}

\section{INTRODUCTION}

Application of chemical pesticides induced harmful effects on plants, soils, human and animals life, since they passed across food chine. So, biological control become very important and pressing need for environment protection. Nematodes are a ubiquitous roundworm of the Phylum Nematoda found in nearly all environments throughout the world. Among 40 families of nematodes associated with insects, only two pathogenic nematode of these families, Steinernematidae and heterorhabditidae, are widely used in biological control, Gaugler and Kaya (1990). These interrestial nematodes are obligate insect parasites Poinar (1979). The infective juvenile stage of the nematode is a free living stage that remains in the soil until it can invade the body of a potential host on contact with a susceptible insect. After infection of the insect host, symbiotic bacteria are released into the insect hemocoel, causing septicemia and death Kaya and Gaugler (1993). The associated with bacterial symbionts, Xenorhabdus spp and Photorhabdus spp Boemare et al (1993), Forst et al (1997). Several studies were conducted by El-Sebay and El-Bishry (1994), who stated that, 
the entomopathogenic nematodes, S. carpocapsae and S. glaseri, resulted good results against subterranean termites Anacanthotermes ochraceus. Woodring and Kaya, (1988), found that nematodes have several distinct advantages over other forms of control in that they are easy to produce, don't require registration by the USEPA, are easy to store, have a high degree of safety among vertebrates and other non-target organisms, and reduce or eliminate the use of chemicals around a structure that is needing treatment. Kaya and Gaugler (1993), stated that, the entomopathogenic nematodes also differ in their abilities to survive in different environmental conditions. Ability to penetrate soil, method of host attack, and ability to handle environmental extremes may favor the use of a particular nematode over another.

In this work we tested the efficacy of interrestial nematode specie, Steinernema scapterisci, (Nematoda: Steinernematidae) Nguyen \& Smart (1990), against subterranean termite, Psammotermes hybostoma in lab., and field by use PVC corrugated card-board trap contained jelly agar as carrier media suitable for nematode life.

\section{MATERIALS AND METHODS}

\section{Termite collections:}

El-Sebay modified trap, (El-Sebay Y. 1991), was used in subterranean termite collection. The collection of $P$. hypostoma, termites were obtained from the infested area. Termites were separated by small brush from the traps and kept in Petri-dishes $(1 \times 9.5 \mathrm{~cm}$ height and diameter, respectively) provided with moistened corrugated card-boards as a source of cellulose and moisture for seven days, then, the healthy workers were used in the test.

\section{Nematode source and Lab., treatments:}

Nematode formulation, Steinernema scapterisci, was provided as a pure culture by Department of Pest Physiology, Plant Protection Research Institute. A stock solution (1000 IJs/ml), was prepared as numbers of IJs (infective juveniles). Three concentrations was prepared by micropipette $(1 \mathrm{ml})$ as follow;

Conc. $1=1000 \mathrm{IJs} / \mathrm{ml}=10 \mathrm{IJs} /$ insect.

Conc. $2=2000 \mathrm{IJs} / \mathrm{ml}=20 \mathrm{IJs} /$ insect.

Conc. $3=4000 \mathrm{IJs} / \mathrm{ml}=40 \mathrm{IJs} /$ insect.

For each treatment, 5 replicates were used (100 termites/Petri-dish). Each treatment contained 100 healthy termites placed in a sterilized Petri-dish. A concentration of the suspension was added to a piece of agar placed beside 
cardboard. All treatments were kept under a constant temperature of $27+1 C^{\circ}$ in an incubator. Daily data were recorded.

The suspension at concentrations of 1000, 2000 and 4000 infective juvenile (IJs/ml) was prepared for test against subterranean termites $P$. hypostoma. Concentrations were chosen on that basis and the micropipette $1 \mathrm{ml}$ was used as follow; dose of $1 \mathrm{ml}, 2 \mathrm{ml}$ and $4 \mathrm{ml}$ were pulled from the three suspensions to equal conc. of 10,20 and $40 \mathrm{IJs} /$ insect, for $1^{\text {st }}, 2^{\text {nd }}$ and $3^{\text {rd }}$ suspensions, respectively. Petridishes ( 1 height $\times 9.5 \mathrm{~cm}$ diameter) were sterilized in an oven at $100 \mathrm{C}^{\circ}$ for 24 hours, and 100 healthy workers of subterranean termites were placed in the Petri-dish. Treatments were replicated five times to equal 500 termites/treatment (conc.). The concentration was added to a piece of jelly agar ( $25 \mathrm{gm})$ as a source of moisture and suitable media of nematodes, placed beside a piece of corrugated card-board ( $5 \times 5$ $\mathrm{cm}$ ) as a source of cellulose for termite. Treatments were kept under a constant temperature $27+1 C^{\circ}$ in an incubator. Mortality was recorded daily for seven days and corrected according Abbott's formula, Abbott (1925).

$$
\text { Corrected } \%=\left(1-\frac{\text { No. in treatment }}{\text { No. in control }}\right) \times 100
$$

The control contained a piece of corrugated card-board $(5 \times 5 \mathrm{~cm})$ and a piece of jelly agar $(25 \mathrm{gm})$, treated with $1 \mathrm{ml}, 2 \mathrm{ml}$ and $4 \mathrm{ml}$ distilled water for concentrations, respectively.

Elbassiouny (2001), used the baits of agar media for nematode, Steinernema carpocapsae (Berliner) against subterranean termites, $P$ hypostoma.

\section{Preparation of Jelly agar:}

Put the amount of agar-agar in boiling water with continuous stirring for $1 / 2 \mathrm{hr}$, and then pour the formulation in aluminum pans and leaves in the laboratory weather to cool and turn into jelly-agar which will be a valid media for nematodes, El-Bassiouny (2001) and El-Dossoki et al. (2009).

\section{Laboratory preparation of trap used in the field:}

PVC corrugated card-board trap consists of El-Sebay modified trap covered by PVC perforated cover which closed from bottom and above, Fig., (1). $25 \mathrm{gm}$ jelly agar were added and putted at the center role of trap as a suitable media of nematodes maintained in nylon sac. Stock suspension of $S$. scapterisci, nematode at concentrations of 1000, 2000 and 4000 infective juvenile (IJs/ml) was prepared at Dept., of Pest Physiology, Plant Protection Research Institute. A micropipette $(1 \mathrm{ml})$ was used to pull suspensions as follow; dose of $1 \mathrm{ml}, 2 \mathrm{ml} 4 \mathrm{ml}$ were pulled from the three suspensions to equal conc. $(1000 \mathrm{IJs} / \mathrm{ml})=10 \mathrm{IJs} /$ insect, $(2000 \mathrm{IJs} / \mathrm{ml})=20$ 
IJs/insect and $(4000 \mathrm{IJs} / \mathrm{ml})=40 \mathrm{IJs} /$ insect, respectively. Doses were pulled and putted directly on $25 \mathrm{gm}$ jelly agar media inside the nylon sac and putted at the trap middle, then, traps were sended directly to field work.

PVC traps were prepared in the termite laboratory, Plant Protection Research Institute, Dokki, Giza, and transmitted to the infested area at Experimental Res. Station Ezz El-Deen region at Ismailia Governorate.

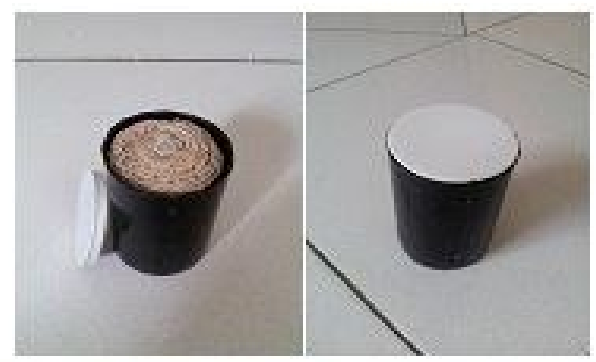

\section{Fig. (1): PVC trap as a bait treated with pathogenic nematode S. scapterisci}

El-Bassiouny and Abd El-Rahman (2011), found that, using the pathogenic nematodes $H$. baujardi and $H$. indica were effective on the two tested termites. The bioagent $H$. baujardi strain was highly effective for control of the two tested subterranean termites, but the subterranean termite $P$. hybostoma was highly susceptible than $A$. ochraceus. The highest rate of mortality started in the $3^{\text {rd }}$ day in all treatments approximately, and decreased gradually to reach stability in $6^{\text {th }}$ or $7^{\text {th }}$ day. The mortality increased as the nematodes concentrations increased and vice versa.

\section{Statistical analysis:}

Statistical analysis of variance was done on all data (ANOVA) and Duncan's multiple range tests was used to separate the means (Snedecor \& Cochran 1980).

\section{Field work:}

100 traps were distributed in infested area, (Experimental Res. Station Ezz ElDeen region at Ismailia Governorate), for discovering colonies places and determination of 35 colonies for 35 different positions as a tested area, infested position were divided to 6 treatments for three conc., and control throughout two successive years 2013 and 2014. First treatment, 15 infested positions were treated once/year with the three conc., of entomopathogenic nematodes (5 infested positions for each conc.). In the same trend, at second treatment, another 15 infested positions were treated 4 times/year "every three months" with the three conc., of entomopathogenic nematodes (5 infested positions for each conc.). 
At $\mathbf{1}^{\text {st }}$ year; 35 traps were prepared in the laboratory treated by Jelly agar without nematode. Traps were buried underground on $15 \mathrm{~cm}$ depth level and distributed in 35 infested positions. Each trap position was stable and numbered throughout two successive years. $500 \mathrm{ml}$ water was soaked on each trap after burring in ground directly. Traps were renewed monthly to record population density throughout the 12 months for each trap.

At $2^{\text {nd }}$ year; 30 traps were prepared for the 6 treatment in the laboratory, Jelly agar was added for each trap as suitable media, and the dose of tested nematode was injected on this media, in addition to 5 trap positions without nematode were added as control. Infested traps were investigated monthly and sended again to lab in Cairo for examination. Termites were separated by small brush from the traps and recorded. Died individuals were kept separately in sterilized petridish provided with a piece of moistened corrugated card-board and examined for seven days to detect nematode development, El-Bassiouny (2001). Data of reduction were corrected according to Henderson and Tilton formula, Henderson \& Tilton (1955).

$$
\begin{aligned}
& \text { Corrected } \%=\left(1-\frac{C \text { before } \times T \text { after }}{C \text { after } \times T \text { before }}\right) \times 100 \\
& C=\text { Control } T=\text { Treatment }
\end{aligned}
$$

\section{Statistical analysis:}

Data was subjected to analysis of variance (ANOVA) and the means were compared by LSD test at 0.05 , using SAS program (SAS, 1988).

\section{RESULTS AND DISCUSSION}

\section{Effect of $\boldsymbol{S}$. scapterisci, against termite $\boldsymbol{P}$. hypostoma, in Laboratory:}

Data in Table (1), showed that, average mortality numbers of pathogenic nematodes $S$. scapterisci, when used of $1000 \mathrm{IJs} / \mathrm{ml}$ (10 IJs/insect), were $0.2,5,16$, $17,11.2,4.8$ and 1.2 in $1^{\text {st }}, 2^{\text {nd }}, 3^{\text {rd }}, 4^{\text {th }}, 5^{\text {th }}, 6^{\text {th }}$ and $7^{\text {th }}$ days respectively, with total average $(53.4 \%)$ for all replicates against subterranean termite $P$. hybostoma. The mortality began after $24 \mathrm{hr}$ and gradually increased until it reached a maximum on the $4^{\text {th }}$ day and then gradually decreased until the $7^{\text {th }}$ day. The average mortality numbers of termite were $0.4,8.6,15.4,21.6,16.8,6.2$ and 2.4 when $2000 \mathrm{IJs} / \mathrm{ml}$ (20 IJs/insect) was used, also mortality began after $24 \mathrm{hrs}$ and recorded total average of (71.4\%) after 7 days of treatment. In case of conc., $4000 \mathrm{IJs} /$ insect, (40 IJs/insect) data were $0.4,17.8,21,24.2,14.2,11.6$ and 3.2 began after the $24 \mathrm{hr}$ until reached to $7^{\text {th }}$ day, with total average (94.4\%). Total mortality average after 7 days in control was $(1 \%)$. 
In all treatments, the small workers (nymphs) of subterranean termites were more susceptible represented the most mortalities in the $1^{\text {st }}$ and $2^{\text {nd }}$ day and died faster than adult workers and soldier respectively. The contaminated termites with pathogenic nematodes were checking up and showed sluggish, body tissues were ragged, explosion in the abdominal area and the Juveniles were out from the soft body area between the head and thorax.

Table 1. Mean of died termites, P. hybostoma treated with S. scapterisci nematode

\begin{tabular}{|c|c|c|c|c|c|c|c|c|c|}
\hline \multirow{2}{*}{ Conc. } & \multirow{2}{*}{ Rep. } & \multicolumn{7}{|c|}{ Non-cumulative mortality in days } & \multirow{2}{*}{$\begin{array}{c}\% \\
\text { Total }\end{array}$} \\
\hline & & $1^{\text {st }}$ & $2^{\text {nd }}$ & $3^{\text {rd }}$ & $4^{\text {th }}$ & $5^{\text {th }}$ & $6^{\text {th }}$ & $7^{\text {th }}$ & \\
\hline \multirow{6}{*}{$1000 \mathrm{IJs} / \mathrm{ml}$} & 1 & 0 & 3 & 9 & 10 & 11 & 2 & 0 & 35 \\
\hline & 2 & 0 & 8 & 12 & 15 & 9 & 4 & 1 & 49 \\
\hline & 3 & 1 & 0 & 29 & 15 & 13 & 7 & 2 & 57 \\
\hline & 4 & 0 & 0 & 18 & 23 & 13 & 4 & 0 & 58 \\
\hline & 5 & 0 & 14 & 12 & 22 & 10 & 7 & 3 & 68 \\
\hline & Mean & 0.2 & 5 & 16 & 17 & 11.2 & 4.8 & 1.2 & $53.4 \%$ \\
\hline \multirow{6}{*}{$2000 \mathrm{IJs} / \mathrm{ml}$} & 1 & 2 & 13 & 17 & 24 & 22 & 5 & 3 & 86 \\
\hline & 2 & 0 & 10 & 18 & 22 & 11 & 10 & 1 & 72 \\
\hline & 3 & 0 & 9 & 21 & 10 & 20 & 11 & 0 & 71 \\
\hline & 4 & 0 & 0 & 11 & 31 & 17 & 2 & 6 & 67 \\
\hline & 5 & 0 & 11 & 10 & 21 & 14 & 3 & 2 & 61 \\
\hline & Mean & 0.4 & 8.6 & 15.4 & 21.6 & 16.8 & 6.2 & 2.4 & $71.4 \%$ \\
\hline \multirow{6}{*}{$4000 \mathrm{IJs} / \mathrm{ml}$} & 1 & 0 & 20 & 21 & 23 & 15 & 11 & 6 & 96 \\
\hline & 2 & 1 & 17 & 30 & 15 & 14 & 11 & 3 & 91 \\
\hline & 3 & 0 & 23 & 15 & 29 & 19 & 9 & 2 & 97 \\
\hline & 4 & 0 & 12 & 21 & 28 & 13 & 17 & 2 & 93 \\
\hline & 5 & 1 & 17 & 18 & 26 & 10 & 10 & 3 & 95 \\
\hline & Mean & 0.4 & 17.8 & 21 & 24.2 & 14.2 & 11.6 & 3.2 & $94.4 \%$ \\
\hline \multirow{6}{*}{ Control } & 1 & 0 & 0 & 0 & 1 & 1 & 0 & 0 & 2 \\
\hline & 2 & 0 & 0 & 0 & 0 & 0 & 0 & 0 & 0 \\
\hline & 3 & 0 & 0 & 0 & 0 & 0 & 0 & 0 & 0 \\
\hline & 4 & 0 & 0 & 0 & 2 & 1 & 0 & 0 & 3 \\
\hline & 5 & 0 & 0 & 0 & 0 & 0 & 0 & 0 & 0 \\
\hline & Mean & 0 & 0 & 0 & 0.6 & 0.4 & 0 & 0 & $1 \%$ \\
\hline
\end{tabular}

Conc. $1=1000 \mathrm{IJs} / \mathrm{ml}=10 \mathrm{IJs} /$ insect

Conc. $2=2000 \mathrm{IJs} / \mathrm{ml}=20 \mathrm{IJ} /$ insect

Conc. $3=4000 \mathrm{IJs} / \mathrm{ml}=40 \mathrm{IJ} /$ insect

The statistical analysis in table (2), showed, significantly differences among the treatments and the LSD at 0.05 was 1.665 .

Table 2. Mean number, range test and LSD 0.05 of died termites $P$. hybostoma treated with $S$. scapterisci nematode

\begin{tabular}{|l|l|l|}
\hline Rank mean name & Mean & Non-Significant range \\
\hline $1-4000 \mathrm{IJs}$ & 13.2 & $5 \mathrm{a}$ \\
\hline 2- $2000 \mathrm{IJs}$ & 10.2 & $5 \mathrm{~b}$ \\
\hline 3- $1000 \mathrm{IJs}$ & 7.92 & $5 \mathrm{c}$ \\
\hline 4- Control & 0.14 & $5 \mathrm{~d}$ \\
\hline LSD $0.05=1.665$ & \\
\hline
\end{tabular}




\section{Relative toxicity of $\boldsymbol{S}$. scapterisci treated on tested termites:}

Data in Table (3) and graphically illustrated as toxicity lines in Fig. (2), show that, the potency of nematode $S$. scapterisci varied tremendously due to the used concentrations. As a general trend, the highest concentration gave the highest rate of mortality. According to the obtained data, different mortality percentages were recorded when the nematode $S$. scapterisci were treated against subterranean termite P. hybostoma. The $\mathrm{LC}_{50}$ and $\mathrm{LC}_{90}$ were 994.73 and $3497.52 \mathrm{IJs} / \mathrm{ml}$ with slop 2.3478 and 2.3478 respectively, and the lower and upper limits/LC 50 $_{0}$ were 0739.41 and 1203.05, while the lower and upper limits/ LC $_{90}$ were 2809.36 and 5023.16 respectively. LDP line program use in the output data.

Table 3. LC values (IJs/ml) of $S$. scapterisci nematode on the termite $P$. hybostoma under laboratory conditions.

\begin{tabular}{|c|c|c|c|c|}
\hline LC & Conc. IJs/ml & Lower limit & Upper limit & Slope \\
\hline $25 \%$ & 513.23 & 0296.62 & 0700.15 & 02.347 \\
\hline $50 \%$ & 994.73 & 0739.41 & 1203.05 & 2.3478 \\
\hline $75 \%$ & 1927.93 & 1643.78 & 2317.93 & 0.1255 \\
\hline $90 \%$ & 3497.52 & 2809.36 & 5023.16 & 2.3478 \\
\hline $95 \%$ & 4995.20 & 3752.89 & 8231.98 & 0.0902 \\
\hline $99 \%$ & 9747.18 & 6360.71 & 21115.2 & 00.979 \\
\hline
\end{tabular}

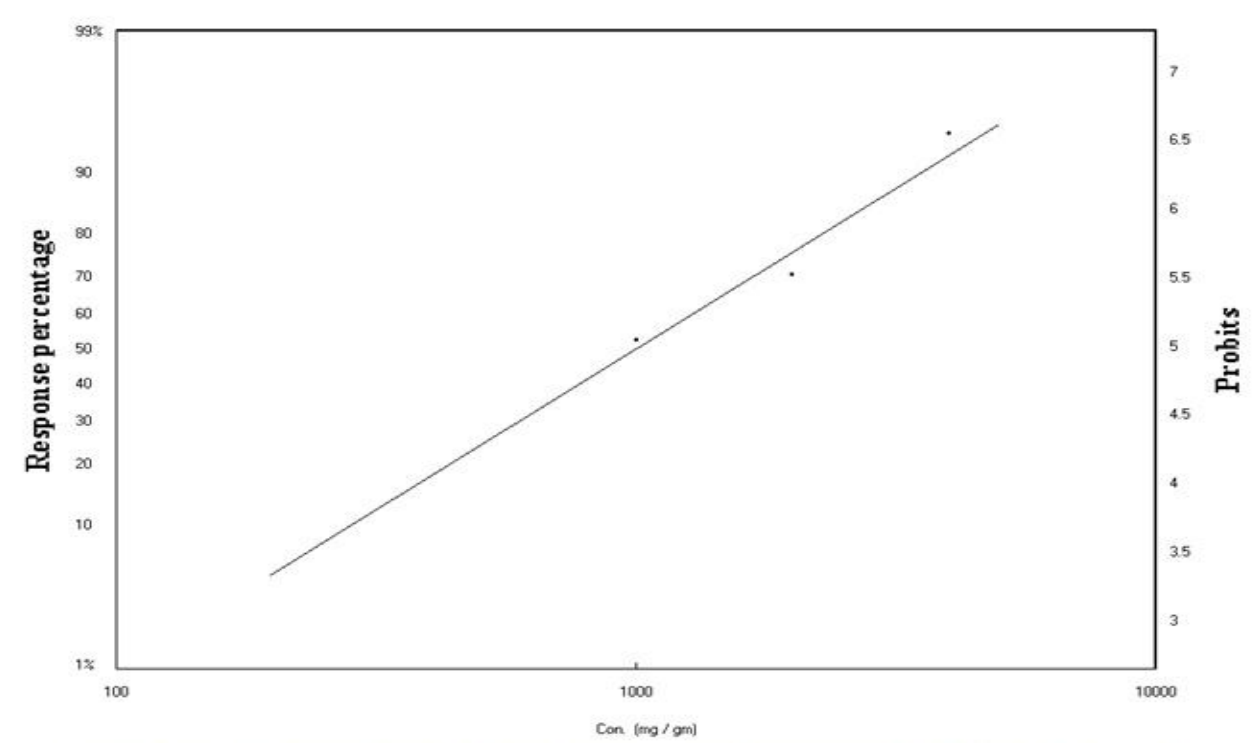

Fig. (2): Toxicity line of S. scapterisci nematode (IJs/ml) treated on $P$. hybostoma, termite under laboratory conditions. 


\section{Effect of s. scapterisci, against termite p. hypostoma, in the field:}

\section{a. Infested position treated once/year}

\section{1- No. of Attracted termites to untreated traps in $1^{\text {st }}$ year:}

At the $1^{\text {st }}$ year 2013; Data in Table (4) showed that, the average numbers of attracted termites $P$. hybostoma in the untreated area (plot 1 ), population numbers counted 2034.0, 1215.3, 2153.1, 1260.0, 3301.2, 1042.8, 1700.0, 0720.0, 0469.3, $2310.1,3500.6$ and 3798.0 individuals with total (23504.4 individuals/year), throughout 12 months, Jan., Feb., Mar., Apr., May, June, July, Aug, Sept., Oct., Nov. and Dec. respectively. In plot (2) the numbers of attracted termites counted 1614.2, 2125.1, 1902.0, 2100.0, 1222.2, 1812.0, 0977.3, 1100.0, 0641.5, 4012.3, 2224.0 and 4100.1 with total (23830.7 individuals/year) around the year months, from January to December respectively. In plot (3), population numbers of termites were 3034.9, 2300.3, 2125.8, 1908.0, 1699.1, 1414.0, 1000.0, 0840.0, 1089.1, 2487.3, 3028.0 and 2200.0 individuals with total (23126.5 individuals/year) in infested area around year months respectively.

\section{2- No. of Attracted termites to treated traps in $2^{\text {nd }}$ year:}

At the $2^{\text {nd }}$ year 2014; in plot (1), average attracted termite numbers of termite into traps treated once/year with conc., $1=1000 \mathrm{IJs} / \mathrm{ml}=10 \mathrm{IJs} /$ insect of entomopathogenic nematode $S$. scapterisci, against sand termite $P$. hybostoma, were recorded in table (4), 0833.3, 0349.3, 0649.1, 0114.0, 3236.0, 1200.0, 2000.0, 0817.5, 0388.1, 2047.2, 3814.0 and 4000.0 with total (19448.5 individuals/year), throughout 12 months, Jan. - Dec. respectively. In plot (2), traps treated with conc. 2 $=2000 \mathrm{IJs} / \mathrm{ml}=20 \mathrm{IJs} /$ insect of nematode, numbers of attracted termites were, 0416.0, 0974.0, 0702.1，1202.8, 1307.7, 1590.3，1000.9, 0897.5, 0734.2, 3710.0, 3105.8 and 4378.0 with total (20019.3 individual/year) from January to December respectively. In plot (3), traps treated with conc. $1=4000 \mathrm{IJs} / \mathrm{ml}=40 \mathrm{IJs} /$ insect of entomopathogenic nematode show that number of attracted termites were 1047.9, 0888.0, 0412.2, 1500.3, 1600.0, 2002.0, 0933.3, 1000.7, 1000.0, 2500.1, 3198.0 and 2000.7 individuals with total (18083.2 individuals/year) throughout the months respectively,

Reduction percentages of subterranean termite $P$. hybostoma, in treated positions were calculated with Excel program, data recorded in (table 6) and illustrated in (fig. 3).

The statistical analysis in (table 4), showed, non significant differences among all treatments. 
Table 4. Average of attracted termite $P$. hybostoma (Desn.) to traps treated with nematode S. scapterisci, once/year during 2013-2014

\begin{tabular}{|c|c|c|c|c|c|c|c|c|}
\hline \multirow{2}{*}{ Months } & \multicolumn{8}{|c|}{ Average attracted no. of termites to untreated traps at (2013) } \\
\hline & Plot 1 & $\%$ & Plot 2 & $\%$ & Plot 3 & $\%$ & Control & $\%$ \\
\hline Jan. & 2034.0 & 08.65 & 1614.2 & 06.77 & 3034.9 & 13.12 & 1805.7 & 07.16 \\
\hline Feb. & 1215.3 & 05.17 & 2125.1 & 08.91 & 2300.3 & 09.94 & 1566.0 & 06.21 \\
\hline Mar. & 2153.1 & 09.16 & 1902.0 & 07.98 & 2125.8 & 09.19 & 1558.0 & 06.18 \\
\hline Apr. & 1260.0 & 05.36 & 2100.0 & 08.81 & 1908.0 & 08.25 & 2159.3 & 08.56 \\
\hline May & 3301.2 & 14.04 & 1222.2 & 05.12 & 1699.1 & 07.34 & 2172.2 & 08.62 \\
\hline June & 1042.8 & 04.43 & 1812.0 & 07.60 & 1414.0 & 06.11 & 1094.0 & 04.34 \\
\hline July & 1700.0 & 07.23 & 0977.3 & 04.10 & 1000.0 & 04.32 & 1335.1 & 05.29 \\
\hline Aug. & 0720.0 & 03.06 & 1100.0 & 04.61 & 0840.0 & 03.63 & 1844.0 & 07.31 \\
\hline Sep. & 0469.3 & 01.99 & 0641.5 & 02.69 & 1089.1 & 04.70 & 2197.6 & 08.72 \\
\hline Oct. & 2310.1 & 09.82 & 4012.3 & 16.83 & 2487.3 & 10.75 & 2811.4 & 11.15 \\
\hline Nov. & 3500.6 & 14.89 & 2224.0 & 09.33 & 3028.0 & 13.09 & 3033.1 & 12.03 \\
\hline Dec. & 3798.0 & 16.15 & 4100.1 & 17.20 & 2200.0 & 09.51 & 3621.1 & 14.37 \\
\hline \multirow[t]{3}{*}{ Total } & 23504.4 & & 23830.7 & & 23126.5 & & 25197.5 & \\
\hline & \multicolumn{8}{|c|}{ Average attracted no. of termites to traps treated once/year at (2014) } \\
\hline & Conc. 1 & $\%$ & Conc. 2 & $\%$ & Conc. 3 & $\%$ & Control & $\%$ \\
\hline Jan. & 0833.3 & 04.28 & 0416.0 & 02.07 & 1047.9 & 05.79 & 1400.0 & 05.70 \\
\hline Feb. & 0349.3 & 01.79 & 0974.0 & 04.86 & 0888.0 & 04.91 & 1816.0 & 07.40 \\
\hline Mar. & 0649.1 & 03.33 & 0702.1 & 03.50 & 0412.2 & 02.27 & 1008.0 & 04.10 \\
\hline Apr. & 0114.0 & 00.58 & 1202.8 & 06.00 & 1500.3 & 08.29 & 2500.7 & 10.19 \\
\hline May & 3236.0 & 16.63 & 1307.7 & 06.53 & 1600.0 & 08.84 & 1898.2 & 07.73 \\
\hline June & 1200.0 & 06.17 & 1590.3 & 07.94 & 2002.0 & 11.07 & 1352.7 & 05.51 \\
\hline July & 2000.0 & 10.28 & 1000.9 & 04.99 & 0933.3 & 05.16 & 1588.0 & 06.47 \\
\hline Aug. & 0817.5 & 04.20 & 0897.5 & 04.48 & 1000.7 & 05.53 & 1576.1 & 06.42 \\
\hline Sep. & 0388.1 & 01.99 & 0734.2 & 03.66 & 1000.0 & 05.52 & 2012.1 & 08.20 \\
\hline Oct. & 2047.2 & 10.52 & 3710.0 & 18.53 & 2500.1 & 13.82 & 2502.0 & 10.20 \\
\hline Nov. & 3814.0 & 19.61 & 3105.8 & 15.51 & 3198.0 & 17.68 & 3000.0 & 12.23 \\
\hline Dec. & 4000.0 & 20.56 & 4378.0 & 21.86 & 2000.7 & 11.06 & 3875.5 & 15.79 \\
\hline Total & 19448.5 & & 20019.3 & & 18083.2 & & 24529.3 & \\
\hline \multicolumn{9}{|c|}{ Statistical analysis (ANOVA) } \\
\hline Year1/2 & \multicolumn{2}{|c|}{ F. value $=0.17$} & \multicolumn{2}{|c|}{$\operatorname{Pr}>$ F. $=0.9135$} & \multicolumn{2}{|c|}{ LSD $=519.33$} & & \\
\hline Year2/2 & \multicolumn{2}{|c|}{ F. value $=1.63$} & \multicolumn{2}{|c|}{ Pr $>$ F. $=0.2018$} & \multicolumn{2}{|c|}{ LSD $=525.12$} & & \\
\hline
\end{tabular}

Conc. $1=1000 \mathrm{IJs} / \mathrm{ml}=10 \mathrm{IJs} /$ insect

Conc. $2=2000 \mathrm{IJs} / \mathrm{ml}=20 \mathrm{IJs} /$ insect

Conc. $3=4000 \mathrm{IJs} / \mathrm{ml}=40 \mathrm{IJs} /$ insect

\section{b. Infested position treated every 3 months ( 4 times/year)}

\section{1- No. of Attracted termites inside untreated traps in $1^{\text {st }}$ year:}

At the $1^{\text {st }}$ year 2013; when traps were untreated, Data in Table (5) showed that the numbers of attracted termites $P$. hybostoma in the untreated area, the numbers of termites were 1334.4, 1305.2, 1451.1, 1046.0, 1120.0, 0950.5, 1300.0, $1150.9,1211.1,1545.1,1620.0$ and 3001.1 individuals with total (17035.4 individuals/year) in infested positions of plot (1) throughout 12 months, Jan. - Dec. respectively. In plot (2) the numbers of termites counted 2015.8, 1870.1, 2051.6, $1500.2,1221.2,1013.3,1070.0,1634.0,2330.2,2717.7,2008.0$ and 3155.0 with total 
(22587.1 individual/year) from January to December respectively. In plot (3), the number of termites were 1621.0, 1140.0, 1123.3, 2332.3, 2360.0, 2000.0, 1882.9, 1700.7, 1000.0, 1631.0, 2080.0 and 1250.5 individuals with total (20121.7 individuals/year) in infested chosen area throughout the months of the year respectively.

\section{2- No. of Attracted termites with treated traps in $2^{\text {nd }}$ year:}

At the $\mathbf{2}^{\text {nd }}$ year 2014; in the same positions of plot (1), traps treated with $1000 \mathrm{IJs} / \mathrm{ml}=10 \mathrm{IJs}$ of entomopathogenic nematode $S$. scapterisci, against subterranean termite $P$. hybostoma, data in table (5), revealed that, the average attracted number of termite were 1110.0, 1004.4, 1350.2, 1200.0, 1000.5, 1060.0, $1005.4,1202.1,1099.9,1140.0,0814.1$ and 2855.0 with a total average (14841.6 individuals/year), throughout 12 months, Jan. - Dec. respectively. In plot (2), traps treated with $2000 \mathrm{IJs} / \mathrm{ml}=20 \mathrm{IJs}$ of entomopathogenic nematode, attracted average numbers of termites, 1214.0, 1521.1, 1700.0, 1215.2, 0866.0, 1000.0, 0798.0, 2011.3, 1733.3, 2802.0, 2124.4 and 2100.0 with total (19085.3 individual/year) from January to December respectively. In plot (3), traps were treated with $4000 \mathrm{IJs} / \mathrm{ml}=$ 40 IJs of entomopathogenic nematode, attracted average number of termites equal 1388.7, 1105.1, 1300.0, 1615.5, 2300.6, 1055.2, 2014.0, 1012.0, 0719.1, 0911.1, 1019.3 and 1102.0 individuals with total (15542.6 individuals/year) throughout the months of the year respectively.

Untreated Plot (4), for all treatments, showed that, termite numbers during the $1^{\text {st }}$ year were $1805.7,1566.0,1558.0,2159.3,2172.2,1094.0,1335.1,1844.0$, 2197.6, 2811.4, 3033.1 and 3621.1 individuals during Jan. - Dec. respectively, with total (25197.5 individuals/year). In the $2^{\text {nd }}$ year, termite numbers were 1400.0 , 1816.0, 1008.0, 2500.7, 1898.2, 1352.7, 1588.0, 1576.1, 2012.1, 2502.0, 3000.0 and 3875.5 individuals with total (24529.3 individuals/year), during the year months respectively.

Reduction percentages of subterranean termite $P$. hybostoma, in treated positions was calculated with Excel program, recorded in (table 6) and illustrated in (fig. 4).

The statistical analysis in (table 5), showed, non significant differences among all treatments. 


\begin{tabular}{|c|c|c|c|c|c|c|c|c|}
\hline \multirow[t]{2}{*}{ Months } & \multicolumn{8}{|c|}{ Average attracted no. of termites to untreated traps at (2013) } \\
\hline & Plot 1 & $\%$ & Plot 2 & $\%$ & Plot 3 & $\%$ & Control & $\%$ \\
\hline Jan. & 1334.4 & 07.83 & 2015.8 & 08.92 & 1621.0 & 08.05 & 1805.7 & 07.16 \\
\hline Feb. & 1305.2 & 07.66 & 1870.1 & 08.27 & 1140.0 & 05.66 & 1566.0 & 06.21 \\
\hline Mar. & 1451.1 & 08.51 & 2051.6 & 09.08 & 1123.3 & 05.58 & 1558.0 & 06.18 \\
\hline Apr. & 1046.0 & 06.14 & 1500.2 & 06.64 & 2332.3 & 11.59 & 2159.3 & 08.56 \\
\hline May & 1120.0 & 06.57 & 1221.2 & 05.40 & 2360.0 & 11.72 & 2172.2 & 08.62 \\
\hline June & 0950.5 & 05.57 & 1013.3 & 04.48 & 2000.0 & 09.93 & 1094.0 & 04.34 \\
\hline July & 1300.0 & 07.63 & 1070.0 & 04.73 & 1882.9 & 09.35 & 1335.1 & 05.29 \\
\hline Aug. & 1150.9 & 06.75 & 1634.0 & 07.23 & 1700.7 & 08.45 & 1844.0 & 07.31 \\
\hline Sep. & 1211.1 & 07.10 & 2330.2 & 10.31 & 1000.0 & 04.96 & 2197.6 & 08.72 \\
\hline Oct. & 1545.1 & 09.06 & 2717.7 & 12.03 & 1631.0 & 08.10 & 2811.4 & 11.15 \\
\hline Nov. & 1620.0 & 09.50 & 2008.0 & 08.89 & 2080.0 & 10.33 & 3033.1 & 12.03 \\
\hline Dec. & 3001.1 & 17.61 & 3155.0 & 13.96 & 1250.5 & 06.21 & 3621.1 & 14.37 \\
\hline \multirow[t]{3}{*}{ Total } & 17035.4 & & 22587.1 & & 20121.7 & & 25197.5 & \\
\hline & \multicolumn{8}{|c|}{ Average attracted no. of termites to traps treated 4 times/year at (2014) } \\
\hline & Conc. 1 & $\%$ & Conc. 2 & $\%$ & Conc. 3 & $\%$ & Control & $\%$ \\
\hline Jan. & 1110.0 & 07.47 & 1214.0 & 06.36 & 1388.7 & 08.93 & 1400.0 & 05.70 \\
\hline Feb. & 1004.4 & 06.75 & 1521.1 & 07.97 & 1105.1 & 07.11 & 1816.0 & 07.40 \\
\hline Mar. & 1350.2 & 09.09 & 1700.0 & 08.90 & 1300.0 & 08.36 & 1008.0 & 04.10 \\
\hline Apr. & 1200.0 & 08.08 & 1215.2 & 06.36 & 1615.5 & 10.39 & 2500.7 & 10.19 \\
\hline May & 1000.5 & 06.74 & 0866.0 & 04.53 & 2300.6 & 14.80 & 1898.2 & 07.73 \\
\hline June & 1060.0 & 07.14 & 1000.0 & 05.23 & 1055.2 & 06.78 & 1352.7 & 05.51 \\
\hline July & 1005.4 & 06.77 & 0798.0 & 04.18 & 2014.0 & 12.95 & 1588.0 & 06.47 \\
\hline Aug. & 1202.1 & 08.09 & 2011.3 & 10.53 & 1012.0 & 06.51 & 1576.1 & 06.42 \\
\hline Sep. & 1099.9 & 07.41 & 1733.3 & 09.08 & 0719.1 & 04.62 & 2012.1 & 08.20 \\
\hline Oct. & 1140.0 & 07.68 & 2802.0 & 14.68 & 0911.1 & 05.86 & 2502.0 & 10.20 \\
\hline Nov. & 0814.1 & 05.48 & 2124.4 & 11.13 & 1019.3 & 06.55 & 3000.0 & 12.23 \\
\hline Dec. & 2855.0 & 19.23 & 2100.0 & 11.00 & 1102.0 & 07.09 & 3875.5 & 15.79 \\
\hline Total & 14841.6 & & 19085.3 & & 15542.6 & & 24529.3 & \\
\hline \multicolumn{9}{|c|}{ Statistical analysis (ANOVA) } \\
\hline Year1/2 & \multicolumn{2}{|c|}{ F. value $=3.84$} & \multicolumn{2}{|c|}{ Pr $>$ F. $=0.0184$} & \multicolumn{2}{|c|}{ LSD $=426.24$} & & \\
\hline Year2/2 & \multicolumn{2}{|c|}{ F. value $=4.92$} & \multicolumn{2}{|c|}{ Pr>F. $=0.0062$} & \multicolumn{2}{|c|}{$\mathrm{LSD}=478.82$} & & \\
\hline & $\begin{array}{l}\text { ר. } 1=100 \\
\text { רc. } 2=200 \\
\text { ר. } 3=400\end{array}$ & $\begin{array}{l}\mathrm{Js} / \mathrm{ml}= \\
\mathrm{Js} / \mathrm{ml}= \\
\mathrm{Js} / \mathrm{ml}=\end{array}$ & $\begin{array}{l}\text { IJs/ insec } \\
\text { IJs/ insec } \\
\text { IJs/ insec }\end{array}$ & & & & & \\
\hline
\end{tabular}

\section{Reduction $\%$ occurred during the $2^{\text {nd }}$ year:}

\section{1- Reduction occurred with treatment once/year:}

Data in table (6) and fig.(3), revealed that, the reduction percentages in termites at conc. 1 were 59.031, 71.258, 69.852, 90.952, 1.975, -15.074, -17.647, $13.541,17.302,11.380,-8.952$ and $-5.318 \%$ with total average $(21.770 \%$ individuals/year). In conc. 2, reduction counted 74.228, 54.166, 63.086, 42.723, $6.995,12.235,-2.414,18.409,-14.450,7.534,-39.649$ and $-6.777 \%$ with total 
average (16.841\% individuals/year). While they were 65.471, 61.396, 80.609, 21.367, $5.832,-41.584,06.67,-19.131,8.181,-0.514,-5.614$ and $9.059 \%$ with total average (15.978\% individuals/year) in case of conc. 3.

\section{2- Reduction occurred with treatment four times/year:}

Data in table (6) and fig.(4), calculated that, the reduction percentages in termites at conc. 1 were 16.791, 23.065, 6.960, -14.722, 10.714, -11.578, 22.692, $4.521,9.248,26.213,49.753$ and 4.865 with total average (11.672\% individuals/year). In conc. 2 , reduction\% counted 39.751, 18.663, 17.113, 19.00, $29.074,1.283,25.420,-23.072,25.622,-3.128,-5.776$ and 33.438 with total average (14.782\% individuals/year). While were $14.373,3.070,-15.761,30.746,2.542,47.25$, $-7.013,40.470,28.1,44.144,51.009$ and 11.84 with total average (20.897\% individuals/year) in case of conc. 3.

\section{3- Reduction occurred in control:}

Data in table (6) and fig.(5), calculated that, the termites reduction percentages in control were 22.467, -15.964, 35.301, -15.810, 12.613, -23.647, $18.942,14.528,8.441,11.005,1.091$ and -7.025 with total average (2.002\% individuals/year) among $1^{\text {st }}$ and $2^{\text {nd }}$ years.

Table 6. Reduction\% of population density occurred after treatment with the tested nematode S. scapterisci, during 2014

\begin{tabular}{|c|c|c|c|c|c|c|c|}
\hline \multirow[t]{2}{*}{ Months } & \multicolumn{3}{|c|}{ treatment once/year } & \multicolumn{3}{|c|}{ treatment 4 times/year } & \multirow{2}{*}{$\begin{array}{l}\text { Reduction } \\
\text { in control }\end{array}$} \\
\hline & Conc. 1 & Conc. 2 & Conc. 3 & Conc. 1 & Conc. 2 & Conc. 3 & \\
\hline Jan. & 59.031 & 74.228 & 65.471 & 16.791 & 39.751 & 14.373 & 22.467 \\
\hline Feb. & 71.258 & 54.166 & 61.396 & 23.065 & 18.663 & 3.070 & -15.964 \\
\hline Mar. & 69.852 & 63.086 & 80.609 & 6.960 & 17.113 & -15.761 & 35.301 \\
\hline Apr. & 90.952 & 42.723 & 21.367 & -14.722 & 19.00 & 30.746 & -15.810 \\
\hline May & 1.975 & -6.995 & 5.832 & 10.714 & 29.074 & 2.542 & 12.613 \\
\hline June & -15.074 & 12.235 & -41.584 & -11.578 & 1.283 & 47.25 & -23.647 \\
\hline July & -17.647 & -2.414 & 06.67 & 22.692 & 25.420 & -7.013 & -18.942 \\
\hline Aug. & -13.541 & 18.409 & -19.131 & -4.521 & -23.072 & 40.470 & 14.528 \\
\hline Sep. & 17.302 & -14.450 & 8.181 & 9.248 & 25.622 & 28.1 & 8.441 \\
\hline Oct. & 11.380 & 7.534 & -0.514 & 26.213 & -3.128 & 44.144 & 11.005 \\
\hline Nov. & -8.952 & -39.649 & -5.614 & 49.753 & -5.776 & 51.009 & 1.091 \\
\hline Dec. & -5.318 & -6.777 & 9.059 & 4.865 & 33.438 & 11.84 & -7.025 \\
\hline Total \% & 21.770 & 16.841 & 15.978 & 11.672 & 14.782 & 20.897 & 2.002 \\
\hline
\end{tabular}




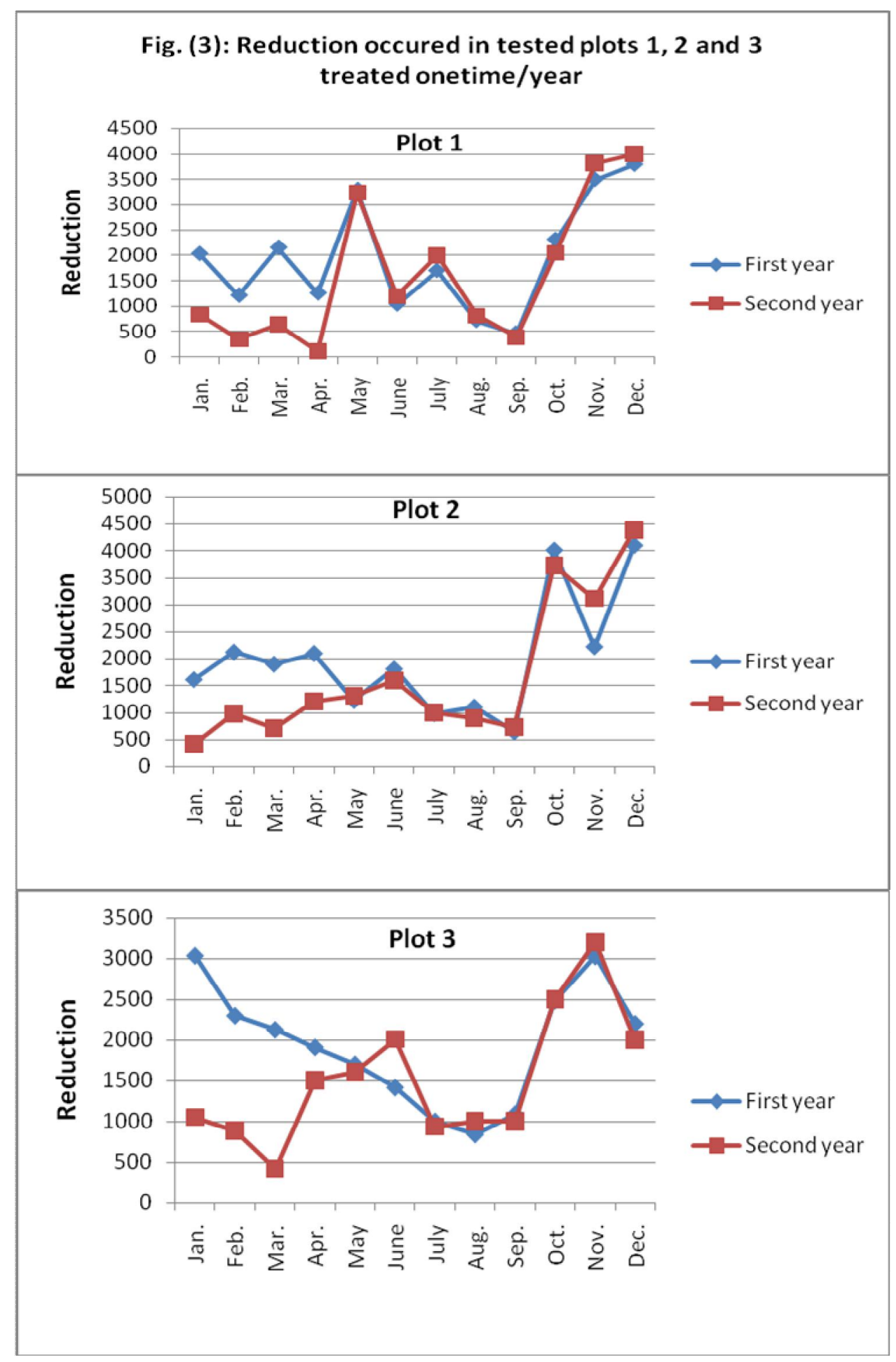




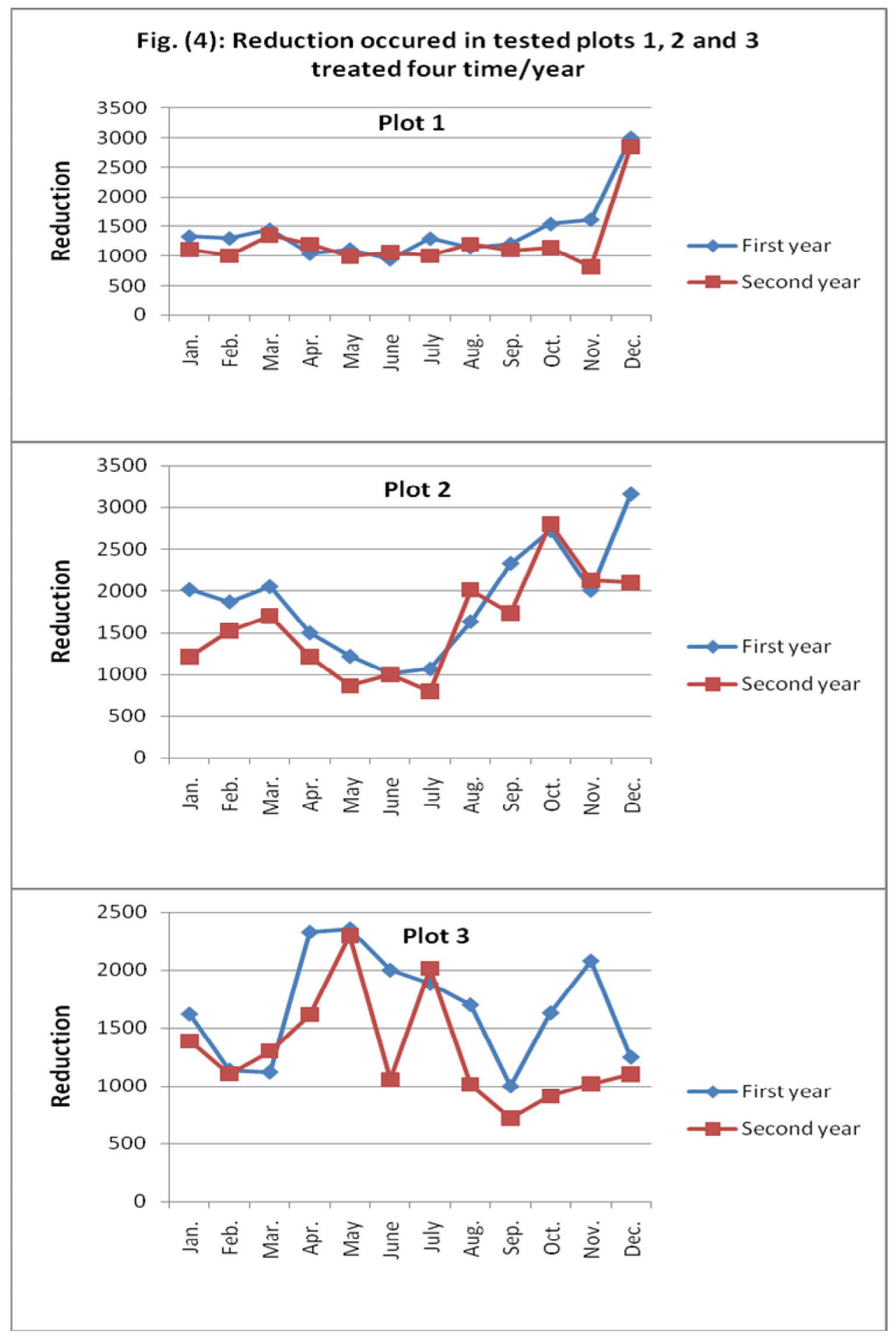




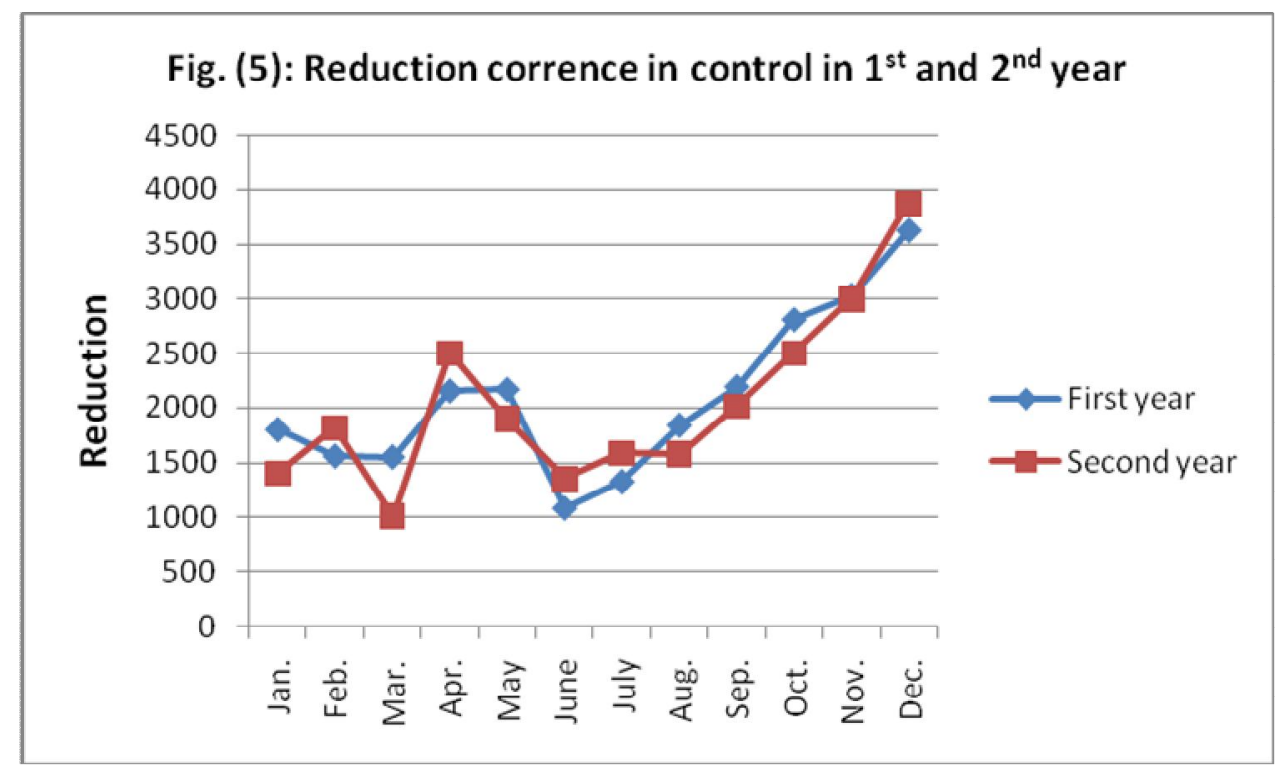

\section{Nematode development and termite symptoms:}

Termites individuals infested with the entomopathogenic nematode were much suffered and sluggish, additional to, tissue body was ragged, abdomen content (mid gut \& hind gut) were exploded and nematode juveniles emerged from body cavity after about Six to Seven days approximately, the emerging occurred specially from soft body regions, prothorax, lateral abdominal regions, anus and the head pits. The small workers (nymphs) were more infected and died faster than the others (adults casts), and represented the most mortalities.

Epsky and Capinera (1988), in United States, studied the potential of entomopathogenus nematode, Steinernema feltiae Filipjev = Neoaplectana carpocapsae (Weisner), Breton strain, for control of a subterranean termite, Reticulitermes tibalis (Banks); they showed that, the termite workers were susceptible to nematodes in laboratory tests, but large numbers of nematodes were required for mortality. $L_{50}$ was estimated as $1.5 \times 10^{4}$ nematodes per termite in standard filter paper assays. Nematodes were applied to the soil directly beneath baited traps at rate of $1 \times 10^{7}$ per $\mathrm{m} 2$ in field trials, and the data revealed that there was a significant difference between treated and untreated traps in number of termites per trap, and protection was provided of 2-3 wk. Termites attacking traps on treated sites and entered traps at a corner or from the top. They suggested that, termites might be avoiding contact with entomogenous nematodes. This study suggests either nematode application should be made frequently or that the entire colony rather than only the feeding site must be treated, and he concluded that, the Reticulitermes tibalis, workers were susceptible to nematodes S. carpocapsae. Mauldin and Beal (1989), 
found that, termites survival rates in the nematode treatment and in the untreated control did not differ significantly. Amarasingh and Homonick (1993 a\&b), found that, S. carpocapsae were better in control of termite psteletrotermes militaris than other isolates tested. El-Sebay and El-Bishry (1994), tested the entomopathogenic nematodes Steinernema carpocapsae and Steinernema glaseri, against subterranean termites $A$. ochraceus, they found that, the $S$. carpocapsae alone was the most effective bioagent followed by $S$. gloseri. Mixing B. T. with S. gloseri enhanced the mortality; the opposite was evident with $S$. carpocapsae, coating the diet with agar as moistening materials increased the efficacy of $B . T$. and $S$. gloseri, while $S$. carpocapsae was negatively affected. Nematode development inside died termites was detected only in case of $S$. gloseri, while $S$. carpocapsae failed to complete its life cycle. Nguyen and Smart (1994), mentioned that using of genus Steinernema as a parasite of termites, resulted that Juveniles nematodes are found outside the termite cadaver, and the diagnosis of Nematodes was accommodate to the termite. Elbassiouny (2001), tested the entomopathogenic nematode Steinernema carpocapsae to control of termite $P$. hybostoma, and found that the termites didn't avoid contact with nematode baits, and fed upon the treated agar; data showed high morality percentages when termites treated with the high conc. $=4 \mathrm{IJs} /$ insect started with 31.4 mortality\% in the second day and reached its maximum $100 \%$ in the sixth day. $\mathrm{LT}_{50}$ was $7.32,3.21$ and 2.23 days for the three conc. $1 \mathrm{IJs} /$ insect, $2 \mathrm{IJs} /$ insect and $4 \mathrm{IJs} /$ insect respectively. The symptom of death of the contaminated termites was suffering, sluggish, tissue bodies are ragged and the juveniles emerged from the body cavity of died individuals after 5-7 days. Juveniles emerged from soft body regions, especially prothorax, lateral abdominal regions, anus and the head pits. The termite workers were more susceptible to nematodes than alates and soldiers. El-Bassiouny and Abd El-Rahman (2011), in Egypt, laboratory study for possibility of using entomopathogenic nematodes $H$. baujardi and Heterorhabditis indica against subterranean termite Psammotermes hybostoma (Desn.), and Anacanthotermes ochraceus (Burm.) were conducted, data showed that, using of tested pathogenic nematodes $H$. baujardi and $H$. indica were effective on the two tested termites. The bioagent $H$. baujardi strain was highly effective for control of the two tested subterranean termites, but the subterranean termite $P$. hybostoma was high susceptible than $A$. ochraceus. In addition to the highly rate of mortality which started in the $3^{\text {rd }}$ day in all treatments approximately, decreased gradually to reach of stability in $6^{\text {th }}$ or $7^{\text {th }}$ day. Overall, the mortality increased as the nematodes concentrations increased and vice versa. 


\section{REFERENCES}

1. Abbott W.S. 1925. A method of computing the effectiveness of an insecticide. J. Econ. Entomol., 18: 265-267.

2. Amarasingh L.D. and W.M. Homonick (1993a): Efficacy of entomopathogenic nematodes to control up-country live wood termite. Sri-Lanka J. Tea Sci., 62 (1): 16-24.

3. Amarasingh L.D. and W.M. Homonick (1993b): Potenianl of using entomopathogenic nematodes to control up-country live wood termite (Postelectrotermes militaris). Sri-Lanka J. Tea Sci., 62 (1): 66-78.

4. Boemere, N.E., R.J. Akhurst, and R.G. Mourant. 1993. DNA relatedness between Xenorhabdus spp.(Enterobacteriacae), symbiotic bacteria of entomopathogenic nematodes, and a proposal to transfer Xenorhabdus luminescens to a new genus, Photorhabdus gen. Nov. Int. J. Syst. Bacteriol. 43:249-255.

5. El-Bassiouny A.R. 2001. A study on the ecology and biological control of subterranean termites, M. Sc. Thesis, Fac., Agric., Al-Azhar University.

6. El-Bassiouny A.R. and Randa M. Abd El-Rahman. 2011. Susceptibility of Egyptian subterranean termite to some entomopathogenic nematodes Egypt J. Agric. Res. 89 (1): 121-135

7. El-Dossoki S.A; S.M. El-Awady; Y. El-Sebay and A.R. El-Bassiouny. 2009. Laboratory evaluation of three bioagent against the Egyptian subterranean termite, Psammotermes hypostoma (Desn.). J. Agric. Res., 87 (1): 13-23

8. El-Sebay Y. (1991): A modified trap for El-Sebay subterranean termites. Fourth Arab Cong. of Plant Protection, Cairo, 1-5 Dec. 1991.

9. El-Sebay Y. and M.H. El-Bishry (1994): Laboratory evaluation of two biocontrol agents against termite Anaconthotermes ochraceus (Burm.). Egyptian J. Biol. Pest Control, 4 (2): 95-100.

10. Epsky N.D. and J.L. Capinera. 1988. Efficacy of entomogenous nematodes Steinernema feltiae against a subterranean termite Reticulitermes tibialis (Isoptera : Rhinotermitidae). J. Econ. Entomol., 81 (5): 1313-1317.

11. Forst, S., B. Dowds, N.Boemare, and E. Stackebrandt. 1997. Xenorhabdus and Protorhabdus spp.: Bugs that kill bugs. Annu. Rev. Microbiol. 51:47-72.

12. Gaugler, R. and H.K. Kaya, Eds. 1990. Entomopathogenic Nematodes in Biological Control. CRC Press 365 pp.

13. Henderson C. F. and Tilton, W. A. 1955. Test with acaricides against the brown wheat mite, Journal of Economic Entomology, 48: 157-161. 
14. Kaya, H.K. and R. Gaugler. 1993. Entomopathogenic Nematodes. Annu. Rev. Entomol. 38:181-206.

15. Mauldin J.K. and R.H. Beal. 1989. Entomogenous nematodes for control of subterranean termites, Reticulitermes spp. (Isoptera: Rhinotermitidae). J. Econ. Entomol., 82 (6): 1638-1642.

16. Nguyen K.B. and G.C. Jr. Smart. 1990. Steinernema Scapterisci n.sp. (Steinernematidae: Nematoda). J. Nematol., 22: 187-199.

17. Nguyen K.B. and G.C. Jr. Smart. 1994. Neosteinernema longicurvicauda n. gen., n. sp. (Rhabditidae: Steinernematidae), a parasite of the termite Reticulitermes flavipes (Koller). J. Nematol., 26 (2): 162-174.

18. Poinar, G.O., Jr. 1979. the natural history of nematodes. Prentice-Hall, Englewood Cliffs, NJ.

19. SAS Institute. 1988. SAS/STAT User`s Guide, Ver. 6.03. SAS Institute Inc., Cary, North Carolina.

20. Snedecor, G.W. and W.G. Cochran. 1980. Statistical Methods, 2nd Ed. The lowa State Univeristy Press, Ames, Lowa, pp. 318.

21. Woodring, J.L. and Kaya, H.K. 1988. Steinernematid and Heterorhabditid Nematodes: A Handbook of Biology and Techniques. Southern Cooperation Series Bull. 331: 30 pp. 


\section{دراسة على إستخدام النيماتودا الممرضة للحشرات ضد النمل الأبيض تحت أرضى}

أيمن رمضان البسيونى ، محمد كمال عباس ، نجلاء فتحى رياض ، راندا محمد عبدالرحمن

$$
\text { معهز بحوث وقاية النباتات - مركز البحوث الزراعية - الدقى - جيزة }
$$

أجريت هذه الدراسة بغرض إمكانية إستخدام النيماتودا الأرضية "شتاينرنيما إسكابترسكاى"

كمرضات ضد النمل الأبيض تحت أرضى "ساموترمس هيبوستوما" تحت الظروف المعملية و الحقلية

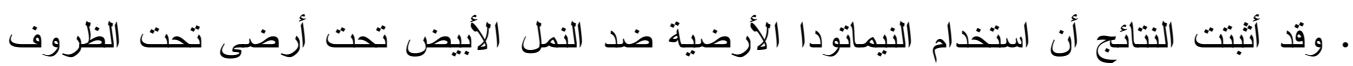

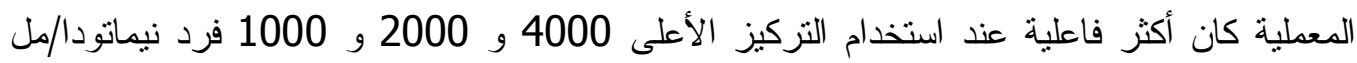
على التو الى حيث وجدت أعلى نسبة موت فى اليوم الرابع و انخفضت تدريجيا حتى وصلت الحد

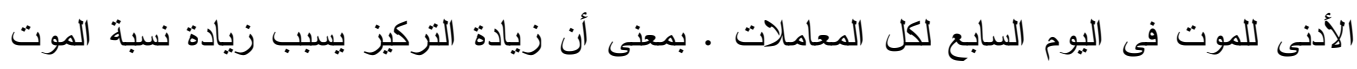

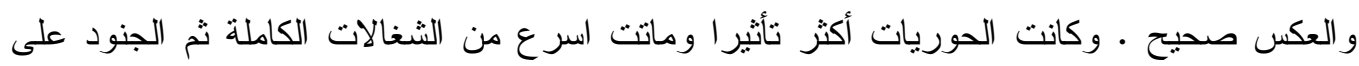

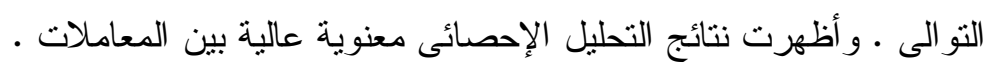

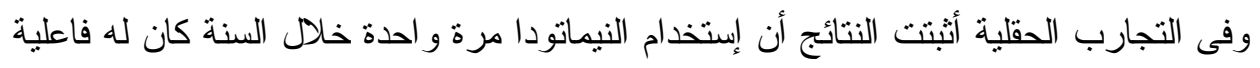
خلال أول ثلاث شهور من المعاملة (يناير وفبر اير ومارس) ضد نوع النمل المختبر ، وعند إستخدام

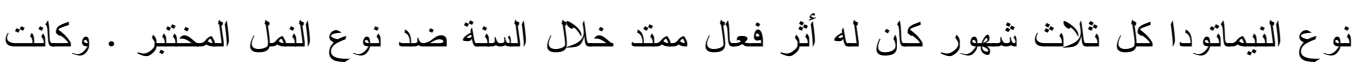
نتائج التحليل الإحصائى غير معنوية لكل المعاملات الحقلية . 